$\begin{array}{ll} & \text { Etnográfica } \\ \text { etnográfica } & \text { Revista do Centro em Rede de Investigação em }\end{array}$

Antropologia

vol. 11 (1) | 2007

Vol. $11(1)$

\title{
East and West: orientalism, war and the colonial present
}

Este e Oeste: orientalismo, guerra e a contemporaneidade colonial

Jackie Assayag

\section{(2) OpenEdition}

\section{Journals}

Electronic version

URL: https://journals.openedition.org/etnografica/1943

DOI: 10.4000/etnografica.1943

ISSN: 2182-2891

\section{Publisher}

Centro em Rede de Investigação em Antropologia

Printed version

Date of publication: 1 May 2007

Number of pages: 253-269

ISBN: 0873-6561; E-ISBN 2182-2891

ISSN: 0873-6561

\section{Electronic reference}

Jackie Assayag, "East and West: orientalism, war and the colonial present", Etnográfica [Online], vol. 11 (1) | 2007, Online since 26 September 2012, connection on 10 February 2022. URL: http:// journals.openedition.org/etnografica/1943; DOI: https://doi.org/10.4000/etnografica.1943

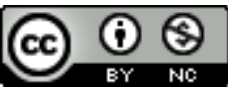

Etnográfica is licensed under a Creative Commons Attribution-NonCommercial 4.0 International License. 


\section{East and West. Orientalism, war and the colonial present}

\section{Jackie Assayag}

For at least two hundred years, Western countries have exercized a "benevolent" violence through colonization. Advocated in the name of the "civilizing mission" of the West and inspired by eschatology, this calling held the promise of redemption, both for the colonizer and for the colonized. The "war declared on terrorism" after the massacre of 9/1 I in New York, with the subsequent military operations in Afghanistan and in Iraq, revives this tradition of ameliorative interventionism by carrying on the old orientalist-related topoi. Far from effacing the Great Divide between the West and the Rest, the wars of a putatively new type reinforce and polarize the division between "civilized" and "barbaric" in the era of "globalization". The unfolding ideology of the American, according to which there would no longer be "outside" or "inside", because no country would now be exempt from terrorism, obscures at little cost, but not ineffectually, the "colonial present". What now prevails is a sombre vision of globalization, that of a fight to the death between two worlds, extending over all continents, between the "Empire of the Good", incarnated by America, and the "Empire of Evil", incarnated by Islamic terrorism. But this novelty goes back to schemas that are as old as the United States itself, insofar as this self-proclaimed "exceptional", "unilateral" and "providential" "imperial republic" has an idealistic or utopian component qualified as "indispensable". Welcome the the "Wilsonism in boots"!

KEYWORDS: empire, colonialism, war, orientalism, United States of America.

To picture an unknown situation, the imagination borrows known elements and for that reason fails to picture it. But the sensitivity, even the most physical, receives like a thunderbolt the original and long indelible signature of the new event.

Marcel Proust, Albertine Disparue

FOR AT LEAST TWO HUNDRED YEARS, THE DISTINCTION BETWEEN AN "internal", within which the values of democracy and liberty are propagated, and an "external", which is never ready to accept them, has led Western countries, like Great-Britain and France, to exercize a "benevolent" violence through colonization. The flaunted objective was to "civilize" the native peoples. Such 
was the "white man's burden". Advocated in the name of the civilizing mission of the West and inspired by eschatology, this calling held the promise of redemption, both for the colonizer and for the colonized. But the aim of making the "others" better went together with a will to power or crusade that imposed at the very least a reform, if not a recasting of their (non) institutions. This pattern of discourse and practices characterizes colonialism in its profound relations with political organizations, also when the latter were democratic. There is a fascinating continuity between past and present regarding the previous justifications of colonialism, punishment and empire. For those who know the French colonial experience, narrated in the well-known movie, Battle of Algiers, for example, it is unbelievable how one is struck by similarities with urban warfare in Iraq and Palestine - who is civilian, who is a combatant, the suspension of any pretense to legality, the rawness of the killing, etc.

The "war declared on terrorism" after the massacre of 9/1 1 in New York, with the subsequent military operations in Afghanistan and in Iraq, revives this tradition of ameliorative interventionism by carrying on the old orientalist-related topoi; conquests by the British of Afghanistan beginning in 1823, of Iraq in 1917-18, of Palestine in 1917. Far from effacing the Great Divide between the West and the Rest, the wars of a putatively new type reinforce and polarize the division between "civilized" and "barbaric" in the era of "globalization".

This unquestionably tragic repetition of history is not surprising. That one might legitimately have doubts as to the lessons of history does not invalidate a brutal observation: the promises of colonialism were always deferred, and thus betrayed, by unfulfilled pledges under the pretext of a difference between "us" and "them", understood in terms of ethnic group or of race, of sex or of culture. Of course, the difference was disputed, contested and frequently denied. And of course, limits or interdictions were overstepped, not to say transgressed. But, that natives would have been able to cross frontiers, bring dividing walls to fall, expunge here and there a few distinctions of rank or profession - in a word, would have become "modern" in one or the other registers of collective life - did not prevent other differences (or the same) from arising (again) in cultures and societies. Who, moreover, can claim to have forgotten the voice of the master when it today splutters, "Educate yourselves; civilize yourselves; reform yourselves; imitate us, but you will never be like us"; you remain "others" - irremediably? The natives will never be modern, unless they are civilized, disciplined, administered, kept watch over, evangelized or guided - in our times, "democratized" manu militari. To enjoy the freedom of the moderns, the natives must remodel their society (nation- or state-building) in the image of that of their master. Obviously, a few empires were able to provide varied contexts of coexistence to a diversity of religious, ethnic, racial and 
cultural groups. But if they were cosmopolitan and sometimes tolerant, it was in part because they were not at all democratic.

The unfolding ideology of the American empire, according to which there would no longer be "outside" or "inside", because no country would now be exempt from terrorism, obscures at little cost, but not ineffectually, the "colonial present". Whatever would be the originality of this empire, it is clear that the old phantoms, but also the unexorcized spectres of political organizations lurking in the past, continue to haunt the imagination of the politically committed actors as well as of the stunned spectators through the avatars of war and peace - the latter also perpetually deferred or travestied. Today, the entrepreneurs of war have created a desert they call peace, to paraphrase Tacitus.

\section{“COLD WAR" OR "HOT WAR”?}

The world does not exist to provide us with illustrations for our theories. Conversely, our theories do not engender the world. Nevertheless, intellectuals are more than ever fascinated by "performatives" or "self-fulfilling prophecies". In fact, the debate on the "clash of civilizations" introduced by the Orientalist pro-sionist Bernard Lewis and amplified by the conservative political scientist Samuel Huntington has transformed religious experiences into political categories devoid of historicity or of contingency. Consequently, this dispute has renewed mutatis mutandis the imaginary geographies of the Orient, which for that matter are more Middle than Far Eastern. ${ }^{1}$ Today, the executioner's crown, and that of the victim and the martyr, incontestably goes to the Muslim. His fiendish figure has taken the place of the diabolic figure of the Communist, as enemy within and without. ${ }^{2}$ It was because the Soviets advocated Marxism that the Americans supported Islam, then the Taliban (even if Islamism cannot be reduced to CIA manipulation, nor "Talibanism" to an "instrumentalization" of the ISI, the Pakistani intelligence agency). ${ }^{3}$ While the "reds" are on the way of extinction in terms of threat, the "greens with beards" abound and wage war everywhere in the world "in the service of Evil", as is emulously repeated. Even though the "United States of Amnesia" did not invent this pattern of discourse - France has done it beforehand - their ideologues and politicians have greatly contributed to its dissemination by supporting radical Muslim movements, simple militants or (more or less powerful) state representatives.

1 The Orientalist did in fact precede the political scientist: "This is no less than a clash of civilizations - the perhaps irrational but surely historic reaction of an ancient rival against our Judeo-Christian heritage, our secular present, and the world-wide expansion of both" (Lewis 1990: 49).

2 This notion is of course borrowed from Edward Said (1978). It was elaborated by Derek Gregory (2004) and Rashid Khalidi (2004), whose works in part inspires our remarks; regarding the image of the "good" and "bad" Muslim, cf. the incisive article by Mahmood Mamdani (2002).

3 Cf. comments on the aforementioned "Afghan affair" in the article by Jackie Assayag (2002b). 
This metamorphosis of cold war enemies has been accompanied by a transformation of the idea of war since the 1980s. While the monopoly of states over high technologies of destruction has been established, less complex technologies have seen an unbridled proliferation. The diffusion of the latter was even encouraged by various geopolitical and mercenary interests, by virtue of the complicity of private intermediaries or of state representatives who employ "revolutionaries" or finance "terrorists". The individuals or groups engaged in warlike activities in Africa, or in certain regions of the Middle East or Asia, are no longer modern states, nor traditional regimes, but are rather a new breed of voluntary actors called "warlords". These warlords are in fact the modern products of a configuration of global and local forces. ${ }^{4}$ Their proliferation has entailed shifts between categories of war entrepreneurs, terrorists, insurgents or those fighting for freedom and ethnic or national liberation, thereby creating ambiguity and uncertainty regarding the roles and aims of each. The simultaneous reconfiguration of terrorism as a sole global force - the aforementioned "Muslim terrorism" - has ultimately subsumed all expressions of violence, protest and vindictiveness under the figure of the "Enemy". This figure, reviled by the politicians in the North, but frequently raised to a hero by a number of media in the South, was conceived as a totality before being vanquished in the interest of universalism incorporated in the American nation. This focalization gave rise to mirror-image effects: the martyrs of Allah henceforth assimilate the destruction of the "Western Enemy" into its numerous impious avatars, the two centres of which are the United States and Israel.

It seems clear today that the complicated situations linked to war and terror in Afghanistan, Pakistan, Kashmir, as well as in Palestine and Iraq, generate communitarian imaginations of catastrophe that encourage political, mafia-like or eschatological bricolages. The scheming intricacies of the "crusade against the axis of evil" provoke aggressive responses, political and cultural, conducive to the extension of lawless zones and to the political implementation of cruelty. All of them foster in the end an economy of fear or of panic that redesigns the architectures of hate and the perimeters of established knowledge and of powers, in the West as in the East, in the North as in the South. ${ }^{5}$

The confrontation of geopolitical cosmologies with the local conceptions of ordinary people in an interconnected world largely influenced by mass media engenders a great many rival intrigues. The proliferation of expositions fosters rumours and the sense of humiliation, nourishes nostalgia as well as resentment, foments fear of conspiracies and fuels the desire for revenge, when it does not arouse mobilizing passions according to divergent, if not contradictory,

4 This is the thesis supported by Olivier Roy (2001) and Nilüfer Göle (2003).

5 For further consideration of this question one can refer to two articles by Jackie Assayag (2002a, 2003). 
interests. The "savage war of peace" - the expression is from Rudyard Kipling and refers to the repression carried out in the colonies - has drawn the front line in terms of "civilization" or "barbarism". Consequently, a multiplicity of actors endeavour to redirect the flow of real or occult powers with a view to reviving the war or establishing peace, as much in villages and neighbourhoods as in the framework of regions and states, as well as in the midst of transnational organizations, notwithstanding their penchant for transparency. ${ }^{6}$

Above all, this horizon of expectation and desire in societies that are more than ever inclined to paranoid crises, in both the South and the North, fosters new connections and previously unknown fragmentations on the basis of narratives that favour spatial and mental fictions incorporating history - teleology or eschatology. Far from bringing the people of the world closer together, the aforementioned globalization engenders "mutual exoticization" inside frontiers and beyond continents: enemies within and without, stereotype against stereotype, reciprocal allocation of hostile prejudices, in short, globalization of insecurity and of fear (Assayag 2005). Thus the modern colonial imagination imposes itself (on the basis of political economy), as the "great [ideological] game" between the empires (Russian and British) was orchestrated in the second half of the nineteenth century (Meyer and Brysac 2002). The colonial present, lying in ambush in minds and clinging on to life, has clear territorial bearings: Afghanistan, Iraq, Palestine; either so many political impasses that illustrate a "besieged cartography", that is to say, an ever-changing configuration of borders, or a production of topological imaginations that are both disputed and derealizing. ${ }^{7}$

The use of cultural registers in a way both emblematic and Manichean - the Muslim, the Good, the Bad, the Occident, etc. - has thus reduced the long history of complex conflicts to an opposition between a unitarian Civilization and numerous barbarisms; "the first victim of war is truth", said Winston Churchill (whose talent in this respect we are chary of contesting). And the same holds on the level of inter-state relations, for the complexity of diplomatic ties appears to be simplified on (at least) the ideological plane. What are (or should be) the relations of states known as "postmodern", such as the United States, Japan and the states of Europe, with so-called "modern" states, such as China, India or Pakistan? How do matters stand (or how should they) as regards the confrontation of these states with the new states in what is called the "pre-modern" geopolitical space that covers grosso modo the heterogeneous

6 On the dialectics of transparency and secret conspiracies in the new world order, cf. the evocative collective work edited by Harry G. West and Todd Sanders (2003) - largely inspired by the works of Jean and John Comaroff.

7 The derealization is particularly pronounced in Palestine, because one has been given to believe for some fifty years that the terror is genetic and not a sociological and political question linked to the Israeli occupation of the aforementioned "territories", this exceptional spectral space that displays topologies of power described as "necropolitics” by Achille Mbembe (2003). 
whole of the former Euro-American colonies? One cannot but observe that this latter space is from the outset considered (by the postmodern states) as the alfresco lair of criminality and the breeding-ground of "international terrorism", fanatic, fundamentalist and suicidal. Within these opaque spaces, risks and dangers grow to the point of threatening the "new world order". Whence, the temptation to treat of the pre-modern chaos according to the good old model tried and tested at the time of colonization (while, however, the postmodern states reject de jure and de facto the principle of colonization). Whence, also, the re-inscription of colonial discourse and its hegemonic practices in the regions of Central Asia and the Middle East by invoking the "exceptional" character of this handful of "rogue states". Designated in this way, these barbarisms are obviously localized in the southern "grey zones" of the planisphere, where dangers are rampant, where the ferocity of uncontrolled fire is concentrated and the risk of generalized wars is fuelled.

A number of North Americans today remain convinced that the territorial division of the world between an Orient filled with darkness and an enlightened Occident persists. But the same people are no less convinced that this opposition covers a deterritorialized cartography of virtue, one associated with the Islamic demon, the other with the Judeo-Christian Good. A contrario, a JudeoChristian-Muslim nation is a notion that a majority of Americans would find un-American. But, would this be different for Europeans? ${ }^{8}$

Thus, the good geographic conscience proves by definition to be Euro-centric. The employment of symbolic and imaginary spaces bears witness to this, as already suggested, but also the treatment of bodies during conflicts or massacres, inasmuch as one accepts "the fastidious algebra of infinite justice", according to the formulation of Arundhati Roy (2001: 105-24). The invisibility of bodies and of carnage, the absence of blood and of mutilations are striking when the victims are Western, in stark contrast to the catastrophes of the Third World, in which the aim (viewed from the West) is precisely to produce the most terrifying details: the veritable horror occurs there, but not here! The reckoning of the local people or the civilians killed during military interventions is always approximate, if not evaded, whereas in the case of Westerners, it is seen to be exact; ${ }^{9}$ as if the massacres of populations of the South would only kill anonymous masses, as if the carnages would involve only a sub-humanity. There, moreover, wars have no witnesses.

8 This idea is brilliantly developed by John Bornman (2003).

9 General Colin Powell admitted that he had "no idea" as to the number of Iraqis killed and that he would not try to find out. Greenpeace estimates that 70.000 to 115.000 Iraqi soldiers and 72.500 to 93.000 Iraqi civilians were killed during the conflict till 2004 (Gregory 2004: 168). An independent group of experts based in London, the Body Project, estimates that the number of civilians killed in the conflict was (in September 2004) between 11.783 and 13.802. 
The intrinsic inequality of the human species is also observed in the use of the category of the Universal: the attack against America was thus interpreted as an attack against Humanity itself. Without wanting to deny the monstrous character of the attac in New York, we will note that a similar judgement never applies to victims of large-scale massacres in the countries of the South; the weak echo caused by the announcement of the genocide that was taking place in Rwanda in 1993 bears witness to this, or the indifference towards the "tropical genocides" perpetrated in Rwanda during colonization in the nineteenth century. ${ }^{10}$ It is indeed unto the death that the nomos of Humanity and the axiological degree reached by cultures is measured. Short of the starchy declarations on the progress or the (reconciled) end of history (in the manner of Francis Fukuyama), and of the allegories of the American Hobbesian Mars and the European Kantian Venus (according to Robert Kagan), there is no choice but to accept the international division of labour and destinies: the burgeoning of the processes of "civilization" in the North, the reign of unmitigated "brutalization" in the South. ${ }^{11}$

\section{NATION, EMPIRE, GLOBALIZATION}

While North America is the main actor in the "preventive" state terror exercised exclusively in what is termed the "Third World", and consequently with a near-general indifference, it is important to realize that the employment of the term "war" (in the declarations of the responsible American politicians) is new. Previously, when governments announced that their duty was "to eradicate terrorists", they took care not to speak of war - a notion linked to the dignity of nation-states and the relations they entertained -, jus ad bellum as well as jus in bello; as if they forbid that the "terrorists" be represented, or that they represent themselves, as enemies, considering that it was only a matter of "criminals". How, in fact, can one declare war on corrupted civilians, fanatic or anarchistic militants, planters of bombs, fundamentalists or presumed nihilists? Even at the time of the worst colonial violence, one spoke of "maintaining order", one organized "police operations", one "cleansed" and justified this "purging" in the name of "pacification". It is true that these acts of terror were then of limited scale, at least in the mother country: the arm of the weak and poor (while state and economic terror is the arm of the strong).

10 One can refer to the work of synthesis by Enzo Traverso (chap. 5: 2002) and to the enlightening investigation conducted by Mike Davis (2001). This idea is also developed in an article by Veena Das (2002). We intentionally leave aside the philosophical discussion of the definition (and the localization) of the "good life", undoubtedly Aristotelian, but given the present circumstances essential from the point of view of the urban paradigm that the capitalist city of New York today constitutes.

11 The interest of the works of the historian George Mosse is to have done away with this distinction by retracing the rise in power of the "culture of war", which reached its acme during the first world conflict of 1914-18; on all of these questions, one can refer to Jackie Assayag (2004a; 2004b). 
The warlike outlook that the American empire allows itself, as a privileged, indeed unique, form is in fact due to its foundation and its history. Its foundation, because the national construction of the United States is based on the denial and extermination of the Indian populations: inaugurated by the famous war against the Pequots, who were annihilated by the Quakers in New England from 1637-38. ${ }^{12}$ Its history, because the United States became a hegemonic power in and through wars. First, the internal war, called the War of Succession, the first modern conflict of the industrial type. Then, the two World Wars, as well as the uninterrupted series of local wars and military interventions (from Korea to Afghanistan and Iraq, by way of Lebanon, the Bay of Pigs, Vietnam, Libya, Panama, Barbados, Chile, Nicaragua, etc.). ${ }^{13}$ These wars, described as more or less "low intensity", aimed at supporting subversion through overthrow (or sometimes support) of governments in the framework of the rivalry with the USSR during and after the "Cold War". In this period, cartography traced a series of borders between "civilization" and "barbarism", well beyond the East-West division, the inscription of which acquires performative, Manichean and often destructive force. Let us also mention the arsenal of economic sanctions devoid of scruples: blockades, embargoes, punitive aerial attacks, army operations, etc. This should remind us that the United States, apart from its participation in the establishment of peace in Europe at the time of the two World Wars, has contributed to the implantation of state terror in the world system, for the benefit of its imperial interests.

The attack of 11 September 2001 was immediately interpreted by a great many North Americans as a myth of destruction of America by an "Enemy" both internal and external, widespread but invisible, tentacular and elusive. Lead by the press and media, whose function was to stabilize the figure of the "Enemy", the community conspired in the "therapeutic patriotism" ${ }^{14}$ It would be a question of itemizing the victims of a massacre conceived following the example of a genocidal eschatology in a country in which one deliberately represented the formation of the nation as an innocent process of self-production, free from violence and immune from contact with other cultures. After this event, the subjective force that bore the Americans in the desire for vengeance and war developed around the flag and the army.

If the United States spends every year for its military budget more than Russia, China, France, England and Germany together, it is because a sizeable number of North Americans are convinced that the interests of the homeland coincide with the "Good", including that of all the populations of the world,

12 On the genocidal foundation of what was not yet the United States, one can refer to the works of Ward Churchill (1997) and David Stannard (1992). On the foundation myths, cf. Élise Marienstras (1976).

13 For an inventory, refer to the works of Noam Chomsky, for example, 2001.

14 The notion is borrowed from the "ethnography of the media" by Carol Gluck (2003). 
which sooner or later derive benefits and redemption. Unable to govern themselves properly, these countries need a (colonial) guardianship distinguishing the "occupied" and the "occupiers" so as to integrate the dominated in the world current of the American way of life. This imposition of protectorship is all the more justified because, in distinction to the British Empire (under a monarchic regime), the Americans discipline the colonized alone by the "virtue of their race" and according to their "perfect liberal democracy", to use the words of Woodrow Wilson. ${ }^{15}$ This translation of Fordism into international relations explains the circle of interventions so as to topple the "rogue states" with a view to reconfiguring them in the image of America: liberal and transparent, mercantile and democratic, prosperous and conquering. Such is the "manifest destiny" of the United States in world history.

Only the blindness of certain neo-conservatives in face of the complexity of social life, as well as their ignorance of the damage caused by the conflicts of nation and empire in the history of the nineteenth and twentieth centuries, has made possible the vision according to which the occupation of a country by force and the subjugation of its population would lead up to the establishment of legality and of social order in the administration of a nation-state in the process of reconstruction (Masson 2004). Thus, the idea that the societies of the South belong to a "permanent state of exception" endures in the thought of the occupier. ${ }^{16}$

\section{HYPERPOWER OR “EMPIRE LITE”?}

The invasion of Afghanistan, and even more so that of Iraq, by the North American army has provoked a debate as to the pertinence of the notion of "empire" in characterizing the military, economic, political and cultural powers of the United States. The anarcho-Marxist work by Michael Hardt and Antonio Negri has thus proposed a postmodern reading of the (post-Roman) American empire under the impact of various mechanisms of transnational regulation that, in particular, consist of the International Monetary Fund (IMF), the World Trade Organization (WTO) and non-governmental organizations (NGOs). ${ }^{17}$ But to once again describe this empire in terms of hegemonic networks and

15 Woodrow Wilson declared in 1901 that: "No Nation can live any longer to itself and the West would necessarily dominate the East. The East is to be opened and transformed, whether we will it or no; the standards of the West are to be imposed on it", cited by Julian Go (2003: 18).

16 On the "state of exception", cf. Gorgio Agamben (2001); Walter Benjamin had already learned this lesson, but "against the grain", in his Theses on the Philosophy of History: "The tradition of the oppressed teaches us that the 'state of emergency' in which we live is not the exception but the rule".

17 To this end, the authors indulge in the mysticism of the sublimation of classes in a deterritorialized, yearning and subversive "multitude", conceived of in a "Deleuzo-Spinozist" manner; this perspective made the book the Bible of the anti-globalists. 
collusion with transnational companies transfixes North American realities by amalgamating its methods of intervention abroad, which should however be distinguished: imperialism (that is to say, intervention in a state without really changing the government); hegemony (to the purpose of establishing the rules of the game that the other actors must respect); colonialism (in the perspective of governing the internal affairs of a subordinate state). ${ }^{18}$

Be that as it may, the notion entertained by responsible North American politicians of the role of territories that have fallen under its empire subsequent to embarking on the "crusade for the Absolute Good against the Absolute Evil" is not congruent with a direct occupation or with a long-term installation. As shown by the cases of Afghanistan and Iraq, the relation created with these vassal and disarmed entities is rather like a client-state relation on the basis of a network of both limited and largely instrumentalized sovereignty. This regime is in many respects like the old notion of "indirect rule" in the context of the British Empire or of the republica de indios in Spanish America. It can be reasonably thought that the American empire could add a series of such client states in the years to come. But this accumulation would not constitute an imperial project in the nineteenth-century sense, that is, a relatively stabilized and accepted order (although the empire was in fact always fragmented, disputed and under tension),${ }^{19}$ nor would it reproduce the type of relations that the United States had in the past with the shah in Iran, or with Pinochet in Chile.

It is conceivable that the United States will utilize its vast resources to organize with greater success the flexibility of global geopolitics. But, on looking at history, it is open to doubt that the coercive temptation to tie this system together under the name of "global liberal democracy" would lead to the planned result. More probably, a system of consensual domination will be imposed in which the North America's coercive power will be selectively used with a view to projects that will give rise to a wider legitimacy and which will be largely supported by local, regional or multilateral institutions. Of course, this "empire" will always be a source of tension, of disorder and violence. But it could be organized here or there in a flexible manner and on a reduced scale of hegemony with which the client states could be variably associated so as to produce better results.

Michael Ignatieff has described (in an uncritical manner) the North American project as an "imperialism lite", a hegemony without colonies, a global sphere of influence relieved of the weight of direct administration

18 Cf. the in-depth historical syntheses on empire by Frederik Cooper (2003; 2004), Emmanuel Saada (2004) and Julian Go (2003). Let us also mention the concept of "non-global hegemon" of Paul Kagan because it remains very much en vogue in the United States.

19 Regarding these dimensions characteristic of colonial empires, cf. Frederik Cooper and Ann Laura Stoller (1997). 
and of the risks entailed in the day to day management of politics. ${ }^{20}$ Thus the "burden" of Kipling would have become lighter in passing from England to the United States, for it is true that the task and the message have in the meantime changed. Today, it is a question of conducting a "war against terrorism". To declare war on individuals and forces liberated from existing legal institutions, or eluding ethical control, proves to be an interminable task. The actors involved in this type of violence in fact freely determine the arms and the targets of their choice, independently of state constraint. Contrary to war according to Clausewitz, the "crusade against terrorism" will not be able to triumph, for it is "the continuation of political absence by other means". ${ }^{21}$ Because of this lack of global politics and because of the deficiency of a world political authority, the multiplication of violent conflicts can be expected.

De facto, one has fallen back on the war against "rogue" or "delinquent" states. The declared imperial will is to destroy them with a view to reforming them according to the advantages of liberal capitalism and of democracy for the benefit of the greatest number. The intention is even to impose the respect for human rights and related cosmopolitan values in the ("foreign" and "hostile") populations, whose major concerns manifestly belong to another order. The concurrent state establishment of the market economy and democratic ideals by means of military force should make nation-building possible and to pacify the "civil society" by ensuring at the same time economic development and growth. Knowing, however, that the Star-Spangled Banner will wave only so long as it is necessary to introduce a free market and the reign of liberty. The hyperpower thus allows itself but a parenthetical empire.

But, how to be a "minimum empire" when one maintains seven hundred and fifty military bases in one hundred and thirty countries, besides numerous programmes of "secret intervention", "silent operation" and "police protection", as well as plans for "virtual bases" that encircle the globe? The only possibility is to temporarily and flexibly implement it, or to enunciate it through disavowal manoeuvres: an empire denied or a denial of empire. Thus the United States sells the notion of empire by offering a cut-price colonization: the responsible Americans now only plan interventions that are as brief as possible, in other words, a "McOccupation". However, this furtive and hardly reliable concept of imperial authority will always be perceived as an invasion and a predation by the "occupied", apart from the fact that such a volatile colonization proves to be full of danger for the "occupiers" as well as the "occupied".

20 The project of "nation-building lite" conceived by Michael Ignatieff (2003) was adopted by the American administration, on one side, the Pentagon, and the neo-conservatives, on the other.

21 We borrow this "Weberian inversion" from Jean Baudrillard, but such as developed by Zygmunt Bauman (2002). 
The idea of a "lite" empire also finds its bearings in the representation according to which such a regime would remove all contradictions, would abolish the distinctions between "outer" and "inner", would efface the borders between "outside" and "inside". "There is no longer an outside", write Michael Hardt and Antonio Negri. In their view, "The modern dialectic of internal and external has been replaced by an interplay of degrees ans intensities, hybridities and artifice". Similarly, the sociologist Zygmunt Bauman contends that 9/1 1 September has made it clear that there is no outside". Hence, the negative corollary posed by a number of observers: with European unification and the emergence of the new world "governance", guided by the enlightened ideas of opening outwards and interdependence, the mutual vulnerability of all countries is growing, also on American territory. Thus, we would have entered into international relations of the "postmodern" type. But, who does not perceive that 9/1 I "a deferred effect of the 'Cold War', the genealogy of which can be traced back to the support of the mujahiddin by the United States against the intervention of the Soviet Union in Afghanistan" (Derrida, in Borradori 2003: 92)? And who could contest that this event experienced as a cataclysm, followed by the wars in Afghanistan and Iraq, apart from the interminable conflict in Palestine, has raised the veil of antagonism between the "colonizer" and the "colonized", radicalized the political positions of each of the entrenched camps and, finally, has deepened the Manichean geography between "us" and "them"?

\section{THE AVATARS OF THE WELTGEIST}

The critique of the perverse effects of political idealism and other eschatological engineering of vast magnitude no longer need be undertaken after the analyses of G.W.F. Hegel, on the Terror, or Karl Popper concerning the waves of contemporary social utopias of "Platonic" inspiration. It must however be observed that the demiurgic will to reconstruct (without mediation) "other" societies (or "of others") to the purpose of improving them is periodically proposed on the political agendas of the great powers and empires. That is to say, a contrario, how much the question of the individual or collective, real or fantasized adversary - beyond the classic question of adversity - hovers over the history of societies in this interminable twentieth century rich in radical and final solutions.

In fact, numerous were the states that designated the adversary as "enemy" with a view to hounding it to better destroy it. And scarcely fewer were those that categorized and then bureaucratized the enemy par excellence to the purpose of annihilating it. The declaration of war in the abstract form of a theatrical or media-staged seizure of the enemy by the state, or rather by the group or class representing it, lent an emblematic shape to this Other - intimate 
and insidious, protean and ubiquitous, inhuman or evil - to the point that its annihilation proves to be an endless process. The relentless pursuit of an elusive enemy, elusive because equivocal or caricatured, augurs for a war without end. ${ }^{22}$

The question of treating the adversary as an "enemy" haunts nations as well as empires. It obsesses them all the more as the response to this question is in limbo: what to do with a person who withholds his assent, announces his disagreement or remains indifferent? Must he be treated as a foreigner, the hostis, or is he to be considered as an enemy? And what treatment is to be reserved for the enemy? For the philosopher, the question of hostility tends to go together with that of difference and identity: it constitutes the blind spot of the future of (in)humanity. But, for the historian and anthropologist, the figure of the enemy is a red thread, or rather the barbed wire, that makes it possible to locate the territories of otherness and to delimit the imaginary spaces of civilization or barbarism, when it does not serve to protect the geography from terrors about everywhere in the world. Carl Schmitt, master that he was of the "friend-enemy" distinction, did not fail to inquire as to the contemporary enigma of "this being, the foreigner, and such that ultimately conflicts with him would be possible that cannot be resolved, neither by a set of general norms established in advance, nor by the sentence pronounced by a reputed uninvolved and imperial third party" (Schmitt 1972: 67); thinly-veiled praise of the "state of exception".

The American strategy, which consists in representing the United States as a "universal nation" articulating global values and combating for this reason the "enemies of civilization": terrorists, tyrants or barbarians, has similarities with the Hegelian version of the Weltgeist; and this all the more so as Mesopotamia is one of the cradles of civilization. ${ }^{23}$ At the beginning of the nineteenth century, Hegel had seen the Weltgeist pass by in the figure of Napoléon, that product of the French Revolution, mounted on a horse at the time of his entrance into the town of Jena. Some one hundred and fifty years later, Theodor Adorno perceived it, not on horseback, but "on the wings of a headless rocket" - an allusion to the V-2s of Hitler, robot-bombs that, like Fascism, "allied the most advanced technical perfection with the most total blindness". At the beginning of the third millennium, the American neo-Straussians think

22 As shown by Omar Bartov (1998), the confusion between executioner and victim is at the heart of the destructive energy characteristic of modern massacres, which are deployed in an imaginary universe that includes every individual in an interminable cycle of devastation and murders.

23 Let us call to mind that this is not the first time that the bombs of British and American powers have rained down on Palestine, Afghanistan and Iraq, regions that the Muslims henceforth think of as three connected invasions. The model of the power of India under the British was applied to Mesopotamia. The Secretary of Foreign Affairs, Lord Curzon, thus proclaimed that "the question of petrol had nothing to do with the occupation of this province...". 
to incarnate the Weltgeist because the United States army - the instrument of the race of lords fighting against the wretches of the earth - has struck down the enemy and smashed the "Axis of Evil" blazoned by Saddam Hussein, the former ally of the West against Iran in the process of "Khomeinization".

Inspired by the neoreaganian cocktail of internationalist idealism and Realpolitik concocted by the conflicting alliance of messianic neo-conservatives (Paul Wolfowitz, Richard Perle), of confederate fundamentalists (George W. Bush, Karl Rove), of imperial nationalists (Richard Cheney, Ronald Rumsfeld) and realist traditionalists (Condoleeza Rice, Colin Powel), ${ }^{24}$ the victory of the "coalition" in Iraq would have justified the use of the armed forces to remodel wide regions where "the damned of the earth" for the greater part live; this dynamic of four schools, thinking diversely about the conflict between virtue, liberty and corruption, is the American "Machiavellian moment", according to the typology of John Pockock. ${ }^{25}$ But the consequences on the "ground" and for the concerned populations of this "Wilsonism in boots" - the formulation is from Pierre Hassner (2003: 199) - allows one to think that it is nevertheless a question of a Pyrrhic victory: the promises of modernization through colonization have been systematically deferred and always supplanted by the ontological difference between "us" and "them" - tertium non datur.

What now prevails is a sombre vision of globalization, that of a fight to the death between two worlds, extending over all continents, between the "Empire of the Good", incarnated by America, and the "Empire of Evil", incarnated by Islamic terrorism. But this novelty goes back to schemas that are as old as the United States itself, insofar as this self-proclaimed "exceptional", "unilateral" and "providential" "imperial republic" has an idealistic or utopian component qualified as "indispensable". It remains that today the (Texan) sheriff is no longer reluctant ${ }^{26}$ to trigger pre-emptive strikes in order to eradicate Evil in the name of the Good and of the universal empire - it's all one.

CNRS, Maison Française, Oxford

24 One can refer to the book by Pierre Hassner and Justin Vaïsse (2003) that deciphers the foreign policy debates in the United States.

25 For the presentation of the four "schools" of foreign politics, those of Alexander Hamilton, Woodrow Wilson, Thomas Jefferson and Andrew Jackson, which the position of George W. Bush confounds, cf. Marc-Olivier Pardis (2004).

26 We twist the formulation ("the reluctant sheriff") of the isolationist ideologue Richard Haass. 


\section{REFERENCES}

AGAmBen, Gorgio, 1997, Homo Sacer. Le Pouvoir Souverain et la Vie Nue. Paris, Seuil (lére éd. Ital. 1995).

ASSAYAG, Jackie, 2002a, “De l'équilibre de la terreur à la planète des risques”, La Revue des Deux Mondes, 2, Février, pp. 49-54.

—, 2002b, "Ethnie, nation, état, empire. À propos des tâlebân et de l'Afghanistan", L'Homme, 162, pp. 291-308.

—, 2003, "Visions fragmentées. Géopolitique des études régionales et mondialisation», Critique, LIX, 679, pp. 946-956.

—_, 2004a, "Leçon de ténèbres. Violence, terreur, génocides", Les Temps Modernes, 626, pp. 275-304.

— , 2004b, “La face cachée de la modernité. Anthropologie et génocides”, L'Homme, 170, pp. $231-244$.

—, 2005, La Mondialisation Vue d'Ailleurs. L'Inde Desorientée. Paris, Seuil (coll. «La Couleur des Idées»).

BARTOV, Omar, 1998, "Defining ennemies, mmaking victims: germans, jews, and the Holocaust", The American Historical Review, 103, 3, 771-816.

BAUMAN, Zygmunt, 2002, "Living and dying in the planetary frontier-land", em Society Under Siege. Cambridge, Polity, 87-1 17.

BORNMAN, John, 2003, "Is the United States Europe's other?", American Ethnologist, 30, 4, 487-492.

BORRADORI, Giovanna, 2003, Philosophy in a Time of Terror: Dialogue with Jürgen Habermas and Jacques Derrida. Chicago, Chicago University Press.

CHOMSKY, Noam, 2001, 11 Septembre. Autopsie des Terrorismes. Paris, Le Serpent à Plumes.

CHURCHILL, Ward, 1997, A Little Matter of Genocide. Holocaust and Denial in the America. San Francisco, City Lights Books.

COOPER, Frederick, 2003, "Modernizing colonialism and the limits of empire", Items \& Issues (Social Science Research Council) 4, 4, 1-9.

—, 2004, "Empire multiplied. A review essay", Comparative Study of Society and History, 247-272.

COOPER, Frederik and Ann Laura Stoller, 1997, Tensions of Empire: Colonial Cultures in a Bourgeois World. Berkeley, University of California Press.

DAS, Vena, 2002, "Violence and translation", Anthropological Quarterly, 1, 105-1 12.

DAVIS, Mike, 2001, Late Victorian Holocaust, El Nino Famines and the Making of the Third World. New York-London, Verso.

GLUCK, Carol, 2003, “Le 11 septembre. Guerre et télévision”, Annales HSS, 58, 1, 135-162. GO, Julian, 2003, "American colonial empire: the limit of power's reach", Items \& Issues (Social Science Research Council) 4, 4, 18-23.

GÖLE, Nilüfer, 2003, "Close encounter: islam, modernity and violence”, em Understanding Suicides Terrorism, <www.interdiscines.org/terrorism $>$.

GRegory, Derek, 2004, The Colonial Present: Afghanistan, Palestine, Irak. Malden-Oxford-Carlton, Blackwell.

HARDT, Michael and Antonio Negri, 2001, Empire. Paris, Éditions de l'Exil.

HASSNER, Pierre, 2003, La Terreur et l'Empire. La Violence et la Paix II. Paris, Seuil (coll. "La Couleur des Idées"). 
HASSNER, Pierre, e Justin Vaïsse, 2003, Washington et le Monde. Dilemme d'une Superpuissance. Paris, Éditions Autrement.

HUNTINGTON, Samuel, 1993, “The clash of civilization?”, Foreign Affairs, 72, 2, 22-49.

IGNATIEFF, Michael, 2003, Empire Lite: Nation-Building in Afghanistan, Kosovo and Bosnia. Toronto, Penguin.

KHALIDI, Rashid, 2004, Ressurecting Empire. Western Footprints and America's Perilous Path in the Middle East. Beacon Press.

LEWIS, Bernard, 1990, "The roots of muslim rage”, Atlantic Monthly, 26, 45-589.

MADANI, Mahmood, 2002, "Good muslims, bad muslims: a political perspective on culture and terrorism”, American Anthropologist, 104, 766-775.

MARIENSTRAS, Elise, 1976, Les Mythes de Fondation de la Nation Américaine. Paris, Maspéro. MASSON, John D., 2004, “Guerre d'Irak et guerre culturelle, les 'pieux mensonges' néo-conservateurs”, Critique 683, 191-208.

MBEMBE, Achille, 2003, "Necropolitics", Public Culture, 15, 11-40.

MEYER, Karl, and Shareen Blair Brysac, 2002, Tournament of Shadows: The Geat Game and the Race for Empire in Central Asia. Washingron, Counterpoint.

PARDIS, Marc-Olivier, 2004, "La culture politique américaine, au singulier et au pluriel", Esprit, Août-Septembre, 114-128.

ROY, Arundhati, 2001, Power Politics. Cambridge, MA, South End Press.

ROY, Olivier, 2001, L'Islam Mondialisé. Paris, Seuil (coll. "La couleur des idées”).

SAADA, Emmanuelle, 2003, "The history of lessons: power and rule in imperial formation", Items \& Issues (Social Science Research Council) 4, 4, 10-17.

SAID, W. Edward., 1991, Orientalism. London, Penguin Books (1.. ed. 1978).

SCHMITT, Carl, 1972, La Notions de Politiques. Paris, Calmann-Levy.

STANNARD, David, 1992, American Holocaust. Oxford, Oxford University Press.

TrAVErso, Enzo, 2002, La Violence Nazi. Une Généalogie Européeenne. Paris, La Fabrique Éditions.

WEST, Harry G., e Todd Sanders (éd.), 2003, Transparency and Conspiracy. Ethnographies of

Suspicion in the New World Order. Durham \& London, Duke University Press.

ZIZEK, Slavoj, 2002, Welcome to the Desert of the Real!. New York-London, Verso. 


\section{Este e Oeste. Orientalismo, guerra e a contemporaneidade colonial}

Jackie Assayag

\section{EHESS}

jackie.assayag@ehesse.fr

Ao longo de pelo menos duzentos anos, os países ocidentais exercitaram uma violência "benevolente" através do colonialismo. Advogado, à época, em nome de uma "missão civilizadora" do Ocidente e inspirado na escatologia, este chamamento invocava a promessa da redenção, tanto para o colonizador como para o colonizado. A declaração de "guerra ao terrorismo" depois do massacre de 11 de Setembro em Nova Iorque, e as subsequentes operações militares no Afeganistão e no Iraque, revive esta tradição de "intervencionismo melhorador" ao transportar os velhos topoi orientalistas. Longe de erradicar a Grande Divisão entre o West e o Rest, as novas guerras reforçam e polarizam a divisão entre "civilizados" e "bárbaros" numa era de "globalização". A crescente ideologia dos norte-americanos, segundo a qual não haveria mais lugar para o "fora" e o "dentro" porque nenhum país está a salvo do terrorismo, ofusca superficialmente (mas também com eficácia) a “contemporaneidade colonial”. Prevalece hoje uma visão sombria da globalização, a visão de uma guerra mortífera entre dois mundos, estendendo-se por todos os continentes e encarnada pelos Estados Unidos da América e pelo "Império do Mal”, encarnado pelo terrorismo islâmico. No entanto, esta nova ordem não faz senão recuperar velhos esquemas, tão antigos como os próprios Estados Unidos da América, na medida em que esta autoproclamada "república imperial", "providencial", "excepcional" e "unilateral" incorpora uma componente idealística e utópica encarada como “indispensável”. Bem-vindos ao “wilsonismo com botas"!

PALAVRAS-CHAVE: império, colonialismo, guerra, orientalismo, Estados Unidos da América. 